\title{
Opinions of Some Nationals (North American, South Korean, Chinese, Indian, Turkish, and Latin American) on Some Concepts of Citizenship Education
}

\author{
Melike Faiz ${ }^{1, *}$, Cengiz Dönmez ${ }^{2}$ \\ ${ }^{1}$ Social Studies Education Department, Faculty of Education, Kastamonu University, Turkey \\ ${ }^{2}$ Social Studies Education Department, Faculty of Education, Gazi University, Turkey
}

Copyright $\bigcirc 2017$ by authors, all rights reserved. Authors agree that this article remains permanently open access under the terms of the Creative Commons Attribution License 4.0 International License

\begin{abstract}
Over years, the meaning of citizenship has changed. This change has occurred as a result of the 21 st century the era of technology as well as changing social perception. Marshall [1] stated that citizenship as members of society and all of these have equal civil, political, social rights and duties. "Citizenship education defined as any conscious or overt effort to develop students' knowledge of government, law and politics as those have evolved through history and presently operate in our society" [2]. Social and moral responsibility is essential for effective citizenship education. Therefore, children should learn self-confidence and socially and morally responsible behavior both in and beyond the classroom, as well as both towards those in authority and among each other [3]. Another essential concept for effective citizenship education is volunteerism, the act or practice of doing volunteer work in community service. A volunteer is a person who does works without getting financial benefits. In addition, diversity is considered essential in citizenship education. Diversity is the acceptance, valorization and understanding of differences among people, such as age, class, ethnicity, race and sex [4]. The purpose of this research is, to investigate the participants' opinions on social and moral responsibilities, volunteerism and diversity. The study involves 28 participants of different nationalities which are namely Turks, North American, South Korean, Latin, Arabs, Chinese and Indian. The study adopts the qualitative research tradition. The data were collected through semi-structured interviews and analyzed via descriptive analysis. It is seen that the participants were willing to be part of voluntary work. The participants stated that diversity is information exchange, a natural phenomenon in the world and variety means wealth and the participants generally felt responsible for a problem in the community they lived in and feel responsible about governmental issues.
\end{abstract}

Keywords Citizenship Education, Social and Moral Responsibilities, Volunteerism, Diversity

\section{Introduction}

In these days, citizenship education has significant importance. Educating good citizens is important for an effective society. Marshall (1997) described citizens as individuals who share a social heritage and are part of that social community [5]. Also Marshall [1] noted that citizenship is a full membership of society and all of the members have equal civil, political and social rights and duties. In this sense, Citizenship education finds "three heads on one body": social and moral responsibility, community involvement and political [3].

Social and moral responsibility is essential for effective citizenship education. Therefore, children should learn self-confidence and socially and morally responsible behavior both in and beyond the classroom, as well as both towards those in authority and among each other [3]. This learning should take place whenever and wherever children work or play in groups or participate in the affairs of their communities. Guidance on moral values and personal development is one of the important preconditions of citizenship [3].

Özmete and Hablemitoğlu [6] stated that diversity has an important place in effective citizenship education. In addition, diversity in society appears as another concept to become a good citizen. Diversity is a changing and developing concept. This term focuses on the social structures, the individual and the content. The differences between variety parts of a society are used to explain mosaics structure [7, 8]. Diversity is the acceptance, valorization and understanding of differences among people, such as age, class, ethnicity, race and sex [4]. Although diversity is a biological term in general, it is also used to distinguish between people and groups [9]. Diversity implies moving beyond the idea of tolerance to a genuine respect for and appreciation of difference. It is central to the idea of pluralism and multi-culturalism and therefore is a cornerstone of education for democratic citizenship [10]. In 
particularly, the dimensions of diversity include gender, religious beliefs, race, marital status, ethnicity, parental status, age, education, physical and mental ability, income, sexual orientation, occupation, language, geographic location, and many more components [11].

Rijamampianina and Carmichael [12] categorize the dimensions of diversity. This includes primary dimensions (race, ethnicity, gender, age and disability), secondary dimensions (religion, culture, sexual orientation, thinking style, geographic origin, family status, lifestyle, economic situation, political trend, work experience, nation) and tertiary dimensions (beliefs, assumptions, perceptions, attitudes, emotions, values, group norms) in 3 groups. The primary dimensions, shape our basic self-image and our fundamental perspective. In addition, they have the most impact on groups in the society. Secondary dimension, exert a more variable in influence on personal identity. The tertiary dimensions are often the core of individual identity and lie deeper below the surface [13]. Moore [7] described the characteristics of diversity as a context dependent, a selective and a relative concept. It is often used as a criterion for vertical and horizontal job segregation and has to do with invisible as well as visible characteristics.

As mentioned before a citizen refers to a person who has ties to a society and in this society all citizens have many differences. Therefore, effective citizenship education has to cover opportunities for exploring perceptions and opposing prejudice and stereotyping. It should also aim at ensuring that diversity is recognized and embraced at the local, national, regional and international level.

Along with social and moral responsibility, diversity and volunteerism is another element in effective citizenship education. Young people around the world participate in volunteer activities in a variety of areas from education to health. The concept of volunteering has different meanings depending on the socio-economic and cultural characteristics of societies. In this case, we can see many different definitions. It has been acknowledged that a number of skills are required for individuals to become active and responsible citizens. One of them is civic-related skills. To participate in volunteering facilities is one of civic-related skills [14]. Volunteering is individuals' taking part in non-governmental organizations and social initiatives. The individual gets involved these activities willingly for the sake of the wealth of community and does not financial benefit from doing such activities [15, 16].

Developed states aim to raise awareness of young and adult citizens in their own interests in order to preserve national values in different ways. When young people participate in voluntary activities they are involved in the society and it helps them to be active [17]. Westheimer and Kahne [18] stated that citizens with personal responsibility are often engaged in voluntary activities. Patrick [19] pointed out that competent and responsible citizens participate in their communities through membership in voluntary civil associations, act politically to accomplish public purposes, have moral and civic virtues, such as responsibility of the common good and they are informed and thoughtful about the principles and practices of democracy. Individuals have a sense of belonging to their country by participating in volunteer activities, thus giving direction to their own lives. Volunteering allows individuals to 'speak' in their countries [20]. A voluntary activity includes 3 main characteristics. The first, it is not an obligation imposed by a contract or law, but an activity carried out by one's free will. Second, it is not carried out in anticipation of a financial provision. Third it is in the public interest [20]. Furthermore Clary and Snyder [21], listed 6 main function of the volunteerism as values (i.e., expressing or acting on important values) understanding (i.e., learning more about the world), enhancement (i.e., growing and developing psychologically), career (i.e., gaining career-related experience) social (i.e., strengthening his or her social relationships), protective (i.e., reducing negative feelings).

Increasing volunteerism at local, national and international levels will contribute to both the community and individual. Volunteering also makes an important contribution to NGO work [16]. An individual is expected to have a sense of belonging in his or her home country. This directly related to individual being a citizen of the country. The concepts of volunteering, diversity and social and moral responsibility are important when individuals have a sense of belonging. The individual must first volunteer for the welfare of the country in which he or she is living and then be responsible for that country. The having respect for each member while being a part of a society is related to the concept of diversity in the citizenship education. For this reason, the views of individuals on moral and social responsibility, diversity and volunteerism are important. The purpose of this study is to find out the opinions of the individuals who from different nationalities.

\section{Materials and Methods}

The purpose of research is to investigate Turkish and some of other national's (Latin American, North American, Chinese, Arabic, South Korean, Turks and Indian) perceptions of social and moral responsibilities, volunteerism and diversity. The study adopts the qualitative research tradition. The data were collected through semi-structured interviews and analyzed via descriptive analysis. When the study group was determined, the convenience sampling type was used from the purposeful sampling types. A convenience sample is a group of individuals who (conveniently) are available for study [22, $23,24]$. While the research group was selected, it was tried to be chosen from the nations which are both easily reached and culturally rich and diverse. Participants from different and diverse cultures were thought to give different answers. 
The study group consisted of 3 Indians, 3 Arabs, 3 Turks, 6 North Americans, 6 South Koreans, 4 Latin Americans and 4 Chinese. The researchers interviewed the participants face to face. Researcher asked the questions on the interview form, as well as the different questions that encouraged the participants to talk.

Semi-structured interviews were conducted with the individuals in the study and the interview form had 4 main questions. In this technique, the researcher prepares an interview protocol. The most important advantage of this technique is that it is more systematic and comparable as the questions are already prepared. However, the researcher can affect the interview in the process, s/he can ask the interviewee to elaborate her/his answers through relevant questions [25]. The phenomenological approach was used in this study. In phenomenology, "the researcher focuses on a particular phenomenon, collects data through in-depth interviews with participants, and then identifies what is common to their perceptions" [22]. Findings obtained from the study are presented in categories and themes by means of descriptive analysis from qualitative analysis methods.

\section{Findings}

\subsection{Findings about the Concept of Volunteerism}

The first question in the interview protocol aimed to find out participants' perceptions of volunteerism. The following questions were asked during the interview:

"What do you think about volunteering? Do you think we need this (volunteerism)? Do you have any of institutions/organizations in your country which have voluntary facilities? And what can you do in terms of volunteerism?"

The tables below show the categories developed from descriptive analysis of the participants answers on these questions.

Table 1. Descriptive Analysis of Latin Americans' Responses

\begin{tabular}{|c|l|}
\hline Latin Americans & f \\
\hline Civil engagement & 3 \\
\hline There are(institutions), but in the big cities & 3 \\
\hline For individuals & 2 \\
\hline Help my country & 1 \\
\hline Can use social media (for awareness) & 1 \\
\hline Help non-citizens & 1 \\
\hline Support for the disabled & 1 \\
\hline We have (institutions) & 1 \\
\hline
\end{tabular}

According to Table 1, three Latin Americans explained volunteerism related to civil engagement. Individuals participate in social life and also political life via volunteerism. He could involve in this process actively. The participants' stated that their countries had institutions related to voluntary work but those were at the big cities (e.g., the capitals). The participants also pointed out that they could help non-citizens (e.g. refugee), disabled children and could use social media to raise awareness.

Table 2. Descriptive Analysis of South Koreans' Responses

\begin{tabular}{|c|l|}
\hline South Koreans & $\mathrm{f}$ \\
\hline It improves social skills & 3 \\
\hline We have(institutions) & 3 \\
\hline It can be local and international & 2 \\
\hline Can do the government doesn't do & 1 \\
\hline Considering the minority & 1 \\
\hline As a graduation requirement for pupils & 1 \\
\hline Non-Profit Organizations & 1 \\
\hline Orphanage/YWCA/Disabilities/Bring briquettes & 4 \\
\hline Civil engagement & 1 \\
\hline
\end{tabular}

According to Table 2, three South Koreans described volunteerism as way to improve social skills. For example, an individual could express himself/herself or could join the others. Following category is that participants' country had institutions related to voluntary work. They also stated that voluntary work can be at local and/or international levels. The participants stated that they could help disabled, bring briquettes to old people and could work at the orphanage or YWCA (Young Women's Christian Association; it helps women).

Table 3. Descriptive analysis of North Americans' Responses

\begin{tabular}{|c|l|}
\hline North Americans & $\mathrm{f}$ \\
\hline Countless opportunities (National, international) & 6 \\
\hline Civil engagement & 6 \\
\hline Secular volunteerism & 1 \\
\hline Can help other communities & 2 \\
\hline Personal contribution & 2 \\
\hline Through churches & 1 \\
\hline
\end{tabular}

According to Table 3, six North Americans stated that their country had countless opportunities related voluntary work. And these were at both national and international levels. In addition, six Americans described voluntary work related to civil engagement. They claimed that individuals feel more connected to where they live. They said that they could contribute to other communities personally.

Table 4. Descriptive analysis of the Arabs' Responses

\begin{tabular}{|c|c|}
\hline Arabs & $\mathrm{f}$ \\
\hline Civil engagement & 4 \\
\hline Bringing together for any charity & 1 \\
\hline Students development & 1 \\
\hline Non-profit organization & 1 \\
\hline Noble work & 1 \\
\hline $\begin{array}{c}\text { Personal experiences (donating money or time/ leadership } \\
\text { and with young leaders) }\end{array}$ & 3 \\
\hline
\end{tabular}


According to Table 4, the participants described that volunteerism related to civil engagement. They claimed that voluntary work could be the most rewarding way to give back to society. Some participants stated that they could get involved in voluntary work through gibing their time and donating money to help others, they could be useful in leadership and guiding young leaders.

Table 5. Descriptive Analysis of the Chinese' Response

\begin{tabular}{|c|c|}
\hline Chinese & f \\
\hline Two sides (for community and individual) & 4 \\
\hline $\begin{array}{c}\text { We have } \\
\text { un-organized }\end{array}$ & 3 \\
\hline $\begin{array}{c}\text { Animal shelters / Voluntary teaching - Volunteering for old } \\
\text { people (Participation) }\end{array}$ & 3 \\
\hline Cannot make changes & 1 \\
\hline
\end{tabular}

According to Table 7, All Chinese participants stated that voluntary work could help both the community and individual. They pointed out that volunteerism could improve a society and help individual to get socialize. Furthermore 3 participants said that their countries had this kind of voluntary institution. Although one person claimed that she/he could not make any changes, others got involved in helping animal shelters, doing voluntary teaching and/or volunteering for the old.

Table 6. Descriptive Analysis of Turks' Response

\begin{tabular}{|c|c|}
\hline Turks & $\mathrm{f}$ \\
\hline We have (institutions:) & 3 \\
\hline Social impact & 1 \\
\hline Individual personality factor & 1 \\
\hline Permanent and sustainable & 1 \\
\hline Nonprofit organization & 1 \\
\hline Association Secretariat/I take part & 3 \\
\hline
\end{tabular}

According to Table 6 three Turks stated that they had voluntary institutions in their country (e.g., Akut/Lösev). They said that they take part in voluntary works for example one of them worked at the association secretariat.

According to Table 7 three participants described that volunteerism related to civil engagement and they stated that they had voluntary institutions in their country. They said that they take part in voluntary works for example medical camps.

Table 7. Descriptive Analysis of Indians' Response

\begin{tabular}{|c|c|}
\hline Indians & $\mathrm{f}$ \\
\hline Civil Engagement & 3 \\
\hline We have & 3 \\
\hline Helping others & 2 \\
\hline Take part (medical camps) & 3 \\
\hline Nonprofit organization & 1 \\
\hline Feeling part of the community & 1 \\
\hline Socialization & 1 \\
\hline
\end{tabular}

Some of examples from individuals about volunteering:

A.5. Volunteering: We do have many opportunities for volunteering in the U.S. I think it is an important way to give back/be a part of the community. Historically in our country many people have done this through their churches. I believe it is still this way somewhat, but it is becoming more secular as well.

I.2. I think volunteering is a good way to give back to the community. We always do need volunteers since it is not always possible to pay people for social work. Social institutions don't usually have that kind of money to boast about. We have multiple institutions like these in India which volunteer for different causes. Personally, I believe every drop makes an ocean. But very few people get up and say they want to volunteer. They usually need to be asked for volunteering. This idea needs to be changed. I want to try and do something in that regard if possible.

C. 3. Volunteering is both conducive to the development of a person and to the whole society. One thing to characterize how developed one society or a nation is to observe how many people are involved in volunteering activities. In China, there are numerous charities that are doing volunteer works and also unofficial individuals/groups doing the same thing. Of course I have been a part of them when I was in high school as well as in college.

\subsection{Findings about the Concepts of Diversity}

The second question in the interview protocol aimed to find out the participants' perceptions of diversity. The following questions were asked during the interview:

"What do you think about diversity? I mean race, religion etc..."

Table 8. Descriptive Analysis of Latin Americans' Responses

\begin{tabular}{|c|c|}
\hline Latin Americans & $\mathrm{f}$ \\
\hline Information exchange & 3 \\
\hline Natural & 3 \\
\hline Nice & 1 \\
\hline Respect & 1 \\
\hline Equal & 1 \\
\hline
\end{tabular}

According to Table 8 three Latin Americans claimed that diversity was a natural phenomenon in the universe. Moreover, it is useful to get information from other cultures, life style and so on. The other participants stated that diversity was like a harmony/mosaic, none of the pieces was better than the other and every person should respect all differences in the country.

Table 9. Descriptive Analysis of the South Koreans' Responses

\begin{tabular}{|c|l|}
\hline South Koreans & f \\
\hline Natural & 1 \\
\hline Enrich with education & 1 \\
\hline Develops culture & 1 \\
\hline Respect & 1 \\
\hline To get information from others & 1 \\
\hline Should communicate with each other & 1 \\
\hline If there is a race, this variety will not happen & 1 \\
\hline
\end{tabular}


According to Table 9 South Koreans also described diversity was natural phenomenon in the universe and it can enrich with the help education. Participants also claimed that diversity can develop culture and it was best way to get information from other people in the world. They also emphasized individuals should respect all the differences in the world and should communicate with each other.

Table 10. Descriptive Analysis of North Americans' Responses

\begin{tabular}{|c|c|}
\hline North Americans & $\mathrm{f}$ \\
\hline Broad-mindedness & 3 \\
\hline Beautiful /Wealth & 2 \\
\hline Increased respect and understanding & 2 \\
\hline Without diversity, the country becomes boring. & 1 \\
\hline America is a unique country because it supports differences. & 1 \\
\hline
\end{tabular}

According to Table 10, two North Americans described diversity as nice and necessary. Moreover, if there is more than one variety, it means you are wealthy because you have more options. They stated that participants learn new information through diversity and diversity develops their point of view. They claimed that diversity could increase respect for others and understanding of others when they met new people.

Table 11. Descriptive Analysis of Arabs' Responses

\begin{tabular}{|c|c|}
\hline Arabs & f \\
\hline Respect & 2 \\
\hline Wealth (Culture and history) & 1 \\
\hline It is important to be proud of your own race. & 1 \\
\hline Understanding & 1 \\
\hline Unchangeable & 1 \\
\hline
\end{tabular}

According to Table 11, Arabs stated that the most important feature of diversity was respect for others and diversity was cultural and historical richness. They said that you couldn't change certain features that made you different from others (e.g. race). One of them claimed that she/he could feel proud of her/his own race.

Table 12. Descriptive Analysis of Chinese' Responses

\begin{tabular}{|c|c|}
\hline Chinese & $\mathrm{f}$ \\
\hline Sharing ideas/ Being knowledgeable & 3 \\
\hline Developing cultural values & 2 \\
\hline America is an example & 1 \\
\hline Two-edged sharp swords (benefit-damage). & 1 \\
\hline Mosaic & 1 \\
\hline Peace & 1 \\
\hline Respect & 1 \\
\hline
\end{tabular}

According to Table 12, two Chinese participants stated that diversity have developed cultural values. Moreover, individuals were sharing ideas and became more knowledgeable about differences through diversity. They claimed that diversity had several benefits and damages therefore it resembled two edged sharp swords. S/he stated that diversity was like mosaic and each and every color in mosaic makes it beautiful.

Table 13. Descriptive Analysis of the Turks' Responses

\begin{tabular}{|c|c|}
\hline Turks & $\mathrm{f}$ \\
\hline Respect for differences & 2 \\
\hline Trying to destroy differences & 2 \\
\hline The development of civilization & 1 \\
\hline Race is not bad but racism is bad & 1 \\
\hline Open-mindedness & 1 \\
\hline
\end{tabular}

According to Table 14, two Turks stated that respect for differences and being open-minded were important. According to them several countries have been trying to eliminate differences between individuals. The other participant stated that race was not bad being a racist was bad. To him, racist people wanted to destroy differences and they have believed their ethnicity was better than the others.

Table 14. Descriptive Analysis of Indians' Responses

\begin{tabular}{|c|l|}
\hline Indians & $\mathrm{f}$ \\
\hline There is a variety in India. & 1 \\
\hline Different opinions / people / history & 1 \\
\hline Country will be boring without diversity & 1 \\
\hline Tolerance & 1 \\
\hline Peace & 1 \\
\hline Character education & 1 \\
\hline Versatile development & 1 \\
\hline
\end{tabular}

According to Table 11, The Indian participant indicated that there were many varieties in India. Thus, they could learn new information and met new people in daily life. One participant claimed that diversity means different opinions, people and histories. Thus, diversity requires respect for others. And it could be improved through character education. Education helps the individual to gain new qualifications related to diversity.

Some of examples from individuals about diversity:

SC 2. It depends on what kind of community it is what my status is. If a community is rather small or if I am one board member, I would feel big responsibility, because the impact of what I do is much bigger in these cases. On the other hand, if it is a big community and I don't take any leading position, I would feel less responsibility.

C.4. "It's a double-edged sword. Diversity provides a lot of benefit, but it also causes problems. USA is a vivid example."

A.2. "The diversity is important for me to have more discussions and to be more proud of my identity with others."

\subsection{Findings about the Concepts of Social and Moral Responsibility}


The third question in the interview protocol aimed to find out the participants' perceptions of social and moral responsibility in any countries s/he lives in. The following two questions were asked during the interview related to social and moral responsibility:

"If you saw some a problem in the community you live in, do you feel responsible for that or you just let it go? Why?"

Table 15. Descriptive Analysis of Latin Americans' Responses

\begin{tabular}{|c|c|}
\hline Latin Americans & f \\
\hline Will do my best & 4 \\
\hline Depends on the problem & 2 \\
\hline Don't want anyone to suffer & 1 \\
\hline Part of the community & 1 \\
\hline Want help from someone who has power & 1 \\
\hline
\end{tabular}

According to Table 15, participants stated that if they had seen some problems in the communities they live in they would have done their best. Two Latin Americans claimed that if the problem was affecting their lives, they would try to solve the problem. One participant stated that he would ask for help from someone who had power. Another participant felt responsible because s/he did not want anyone to suffer due to problems in the society.

Table 16. Descriptive Analysis of South Koreans' Responses

\begin{tabular}{|c|c|}
\hline South Koreans & $\mathrm{f}$ \\
\hline Depends on problem/community/status & 5 \\
\hline Feel responsible & 2 \\
\hline Do not have enough power & 1 \\
\hline Do not feel responsible & 1 \\
\hline Spread in social media (the problem) & 1 \\
\hline
\end{tabular}

According to Table 16, five South Koreans stated that they were feeling responsible but it depended on the problem, community and their social status. If the problem affected his/her life or the problem was big enough, s/he would feel responsible. S/he would also feel responsible if the community was small. While one participant mentioned that $\mathrm{s} /$ he wouldn't feel responsible, another claimed that s/he did not have not enough power to deal with problem. Finally, the last participant highlighted that $\mathrm{s} / \mathrm{he}$ could spread the problem in social media to raise awareness.

Table 17. Descriptive Analysis of North Americans' Responses

\begin{tabular}{|c|c|}
\hline North Americans & $\mathrm{f}$ \\
\hline Depends on the situation & 3 \\
\hline For the best society & 2 \\
\hline For my religion and my children & 1 \\
\hline If I have enough power I will help & 1 \\
\hline America is individualized. & 1 \\
\hline Can't be a leader & 1 \\
\hline Organized groups at the local level & 1 \\
\hline
\end{tabular}

According to Table 17, three Americans claimed that they would feel responsible only if the problem concerns them. Two Americans stated that everyone in society should feel responsible for the best society. A participant underlined that organized groups of individuals could make a difference at the local level. The other participant mentioned that $\mathrm{s} / \mathrm{he}$ could feel responsible because of his/her religion and children.

Table 18. Descriptive Analysis of Arabs' Reponses

\begin{tabular}{|c|c|}
\hline Arabs & f \\
\hline Be part of society & 1 \\
\hline Makes me responsible & 2 \\
\hline
\end{tabular}

According to Table 18, two Arabs stated that they would feel responsible because they were part of community. Every person in society is as a part of there. The other participant claimed that if there was something to do, s/he could do it.

Table 19. Descriptive Analysis of the Chinese' Responses

\begin{tabular}{|c|c|}
\hline Chinese & f \\
\hline Feel responsible & 3 \\
\hline Can be effective all the time. & 1 \\
\hline Thinking deeply & 1 \\
\hline Don't care/Can not do something & 2 \\
\hline
\end{tabular}

According to Table 20 two Chinese participants stated that they didn't care about any problems of where they live in. This can be considered a relatively interesting response as individuals are expected to feel responsible about the problems in their communities. Indeed, three participants stated that they could feel responsible. While one participant mentioned that s/he should think deeply, another claimed that $\mathrm{s} / \mathrm{he}$ could be effective at all time.

Table 20. Descriptive Analysis of Turks' Responses

\begin{tabular}{|c|c|}
\hline Turks & $\mathrm{f}$ \\
\hline Feel responsible (in every case) & 1 \\
\hline Depends on the problem & 1 \\
\hline Depends on the society & 1 \\
\hline
\end{tabular}

According to Table 20, Turks stated that they can feel responsible but it would depend on the situation and/or the society. If it affects individuals' life, s/he will be concerned and/or if her efforts find correspondence in the society, s/he will feel responsible. The other participant mentioned that $\mathrm{s} /$ he could feel responsible in all situations.

Table 21. Descriptive Analysis of Indians' Responses

\begin{tabular}{|c|c|}
\hline Indians & $\mathrm{f}$ \\
\hline Feel responsible. & 1 \\
\hline Do not feel responsible (unless it concerns me) & 3 \\
\hline Talk to someone who will be effective. & 1 \\
\hline
\end{tabular}


According to Table 21, three Indians participants stated that they didn't feel responsible unless the problem concerned them. That is, if the problem affected their lives they could feel responsible. However, one participant claimed that $\mathrm{s} / \mathrm{he}$ could feel responsible in all situations. The other participant stated that $\mathrm{s} /$ he would ask for help from others who could be effective.

Some of examples from individuals about responsibility in where he/she live:

C. 4. "Honestly I probably will just let it go, because I really don't want to get in trouble, although sometimes I do have the impulse to help or outrage for injustice."

T. 2. K22. "If it is a sensible society and my efforts find correspondence in it, I can take responsibility for the issues I care about"

M. 3. "I would participate to address the issue, although, I would most likely not be the one to start the organizing process. I feel that organized groups of individuals can make a difference at the local level."

The fourth and last question in the interview protocol aimed to find out participants' perceptions of social and moral responsibility in their own country in particular. The following question was asked during the interview:

"If you see something wrong in your governments' decisions, do you want to change this? Why?"

Table 22. Descriptive Analysis of Latin Americans' Responses

\begin{tabular}{|c|c|}
\hline Latin Americans & $\mathrm{f}$ \\
\hline Want to change it & 3 \\
\hline It needs power & 1 \\
\hline I am part of the country I will do my best & 1 \\
\hline
\end{tabular}

According to Table 22, three Latin Americans stated that they were generally willing to do something for their country. They wanted to do their best and if nobody attempted to change bad decisions, things would go worse. But the other participant claimed that making such changes would require power.

Table 23. Descriptive Analysis of South Koreans' Responses

\begin{tabular}{|c|c|}
\hline South Koreans & $\mathrm{f}$ \\
\hline Claim his/her rights & 2 \\
\hline To vote & 1 \\
\hline Will do my best & 1 \\
\hline Thinking deeply & 1 \\
\hline
\end{tabular}

According to Table 23, two South Koreans claimed that living in a safe and comfortable place was all citizens' rights, thus they would like to change wrong things about governments' decisions. The other participant stated that voting was the best way to change something wrong. The others stated that $\mathrm{s} / \mathrm{he}$ would do her/his best and $\mathrm{s} / \mathrm{he}$ might need to think thoroughly.

Table 24. Descriptive Analysis of North Americans' Responses

\begin{tabular}{|c|c|}
\hline North Americans & f \\
\hline Feeling responsible & 2 \\
\hline People in the USA have the power to change & 1 \\
\hline Ask for help from others & 1 \\
\hline There's nothing I can do & 1 \\
\hline To vote & 1 \\
\hline
\end{tabular}

According to Table 24, two North Americans stated that they were responsible for changing problems related to the government. One participant underlined that voting was one of the ways to change something; and the other stated that $\mathrm{s} /$ he could not do anything.

Table 25. Descriptive Analysis of the Arabs' Responses

\begin{tabular}{|c|c|}
\hline Arabs & $\mathrm{f}$ \\
\hline Social Media & 1 \\
\hline I am part of my country & 1 \\
\hline Will hope for change & 1 \\
\hline Can solve it in any way. & 1 \\
\hline
\end{tabular}

According to Table 25, one participant stated that $\mathrm{s} / \mathrm{he}$ can use social media for changing something wrong related to government. Another claimed that s/he would merely hope to change something. The last participant stated s/he wanted to change the wrongs because s/he was part of his country.

Table 26. Descriptive Analysis of the Chinese' Responses

\begin{tabular}{|c|c|}
\hline Chinese & F \\
\hline Cannot do anything & 3 \\
\hline A difficult task & 2 \\
\hline A long process & 1 \\
\hline I am willing to change (the wrongs) & 1 \\
\hline Get used to what they do in the country & 1 \\
\hline No request and no power & 1 \\
\hline Depends on problems & 1 \\
\hline Social Media & \\
\hline
\end{tabular}

According to Table 26 Chinese participants do not seem very hopeful in terms of making a change in general. To them, changing could be a long and difficult process; moreover, it might require power. However, one participant stated that use social media could be used for changing the wrongs.

Table 27. Descriptive Analysis of the Turks

\begin{tabular}{|c|c|}
\hline Turks & $\mathrm{f}$ \\
\hline Education & 1 \\
\hline The world is our ship & 1 \\
\hline No motivation and no desire & 1 \\
\hline Do not make any effort & 1 \\
\hline
\end{tabular}

According to Table 27, one of the participants claimed that if you educated individuals, they would feel responsible for governmental affairs. Another participant told that every person in the world should feel responsible and do their best because we live in the same world. However, the other participant stated that $\mathrm{s} /$ he would not make any effort because $\mathrm{s} /$ he did not have any personal motivation or desire. 
Table 28. Descriptive Analysis of Indians' Responses

\begin{tabular}{|c|c|}
\hline Indians & $\mathrm{f}$ \\
\hline Complex process & 2 \\
\hline Requires majority's involvement & 2 \\
\hline Write about what I want to change & 1 \\
\hline Education & 1 \\
\hline Will do my best & 1 \\
\hline Cannot do anything & 1 \\
\hline Wanting and taking an action are not same & 1 \\
\hline Social Media & 1 \\
\hline
\end{tabular}

According to Table 28, two Indians stated that changing something could be a long and complex process and it might require majority's participation. Other Indians stated that they could use social media, educate people and/or write about it to stand up against the wrongs.

Some of examples from individuals about responsibility in country:

T. 3. "I think the government's actions have done wrong. Of course I want to intervene in the mistakes made. But this is not only a problem with the country and the government. In general, the world is our ship. I'd like to make a comeback for the ship not to sink."

C. 5. "As a Chinese citizen, we've already gotten used to what our government did. We don't have the ability, even the will to improve it."

I. 1. "Yes, I would want to change that wrong thing whether it be in government or in a society. I don't see government to be an alien entity from our society so wherever, I see a problem I try to do whatever at my level no matter how miniscule it may be."

\section{Conclusions}

\subsection{Result}

In light of the findings presented above, it is possible to list the following results;

- When we evaluate the findings about volunteerism, the participants were willing to be part of voluntary work. While some stated that they had done voluntary work, some pointed out that there were not enough facilities related to voluntary work in their countries. Furthermore, civil engagement has become the most repeated category in this section. The participants stated that one of the most important things in being a part of society is civil engagement. This can improve social skills as well. When young people participate in voluntary activities they are involved in the society and it helps them to be active citizens [17]. Moreover, increasing volunteerism at local, national and international levels will contribute to both the community and individual [16].
- When we evaluate the findings about diversity, the participants stated that generally diversity is information exchange, a natural phenomenon in the world and variety means wealth. In addition, they highlighted that diversity requires respect and tolerance. But one of the participants stated, "When I learn about the others, I can be proud of my ethnic." This response can be considered interesting because the related literature indicates that one race is not superior to another [26]. Diversity is the acceptance, valorization and understanding of differences among people, such as age, class, ethnicity, race and sex [4]. Moreover, primary dimension of diversity an individual has no control over these characteristics. These characteristics are assigned at birth, such as age, race, ethnicity, gender, and physical ability. These characteristics are the sources of prejudice and discrimination [27].

- When we evaluate the findings about responsibility, the participants generally felt responsible for a problem in the community they lived in. In addition, "depending on the problem" was one of the most repeated categories. In this case, individuals need to know the problem in detail to feel responsible (e.g., if it concerns them). However, some of them did not feel responsible and this might not be very beneficial for the society and citizenship education. Citizenship education in fact requires individuals' responsibility [14, 28, 29]. Social and moral responsibility is essential for effective citizenship education. Therefore, children should learn self-confidence and socially and morally responsible behavior both in and beyond the classroom, as well as both towards those in authority and among each other) [3].

- Participants generally feel responsible about governmental issues. They stated that changing something needs a complex process and majority's involvement. And they stated that educating individuals could lead to a more responsible society. When we examine the results about responsibility, we came across "depending on the situation" as one of the most frequent responses and this may result in questionable outcomes for the sake of common wealth [3]. Effective and good citizenship is an individual's sense of social and moral responsibility. Social and moral responsibility finds its reflection in behavior that is juts and fair. Respect for authority in a community is an important aspect of [31].

\subsection{Suggestion}

- This study was adopting the qualitative research tradition. The data were collected through semi-structured interviews. In addition to this, other data collection tools and methods can be used in future studies. 
- The study group involves only adults from 7 nations in this research. A study can be carried out with a different sampling (e.g., adolescence, seniors, more/other nationalities).

- Other relevant key concepts (e.g., equality, democracy) can be focused on in future studies.

- Opportunities must be provided for individuals to recognize different groups. For this reason, individuals' language learning needs to be improved. Thus, they can communicate with each other. It may be possible to use country visits or social media.

- Appropriate opportunities should be provided to carry out volunteer work. Moreover, voluntary activities are required for entry into employment. So individuals have to participate in voluntary works.

- In some countries (e.g. Turkey...), universities have courses such as "community services" and "social projects." This course enables students to undertake responsibilities. The work done by non-governmental organizations in the community is carried out by the facilities of the university. Such activities can also be held at primary, secondary and high school levels.

\section{REFERENCES}

[1] Marshall, T. H. (1950). Citizenship and Social Class, and other essays Cambridge: Cambridge University.

[2] Hoge, J. D. (2002). Character education, citizenship education, and the social studies. The Social Studies, 93(3), $103-108$.

[3] Advisory Group on Citizenship. (1998) Education for citizenship and the teaching of Democracy in schools. London: Qualifications and Curriculum Authority. Retrieved on the 10.05.2014 fromhttp://dera.ioe.ac.uk/4385/1/crickrepo rt1998.pdf.

[4] Esty, K., R. Griffin \& M. Schorr-Hirsh. 1995. Workplace diversity. A manager's guide to solving problems and turning diversity into a competitive advantage. Avon, MA: Adams Media Corporation.

[5] Olssen, M. (2002). Citizenship education and difference. Citizenchip Education and the Curriculum, 2, 7-27.

[6] Özmete, E. \& Hablemitoğlu, S. (2012). Etkili vatandaşlık eğitimi için bir öneri, Ankara Sağlık Bilimleri Dergisi, 1(3), 39-54.

[7] Moore, S. (1999). Understanding and managing diversity among groups at work: Key issues for organizational training and development. Journal of European Industrial Training, 23, 208-217.

[8] Tsui, A. S., Egan, T. D., \& O’Reilly, C. A., III. 1992. Being different: Relational demography and organizational attachment. Administrative Science Quarterly, 37: 549 -579.

[9] Wing Sue, D., Rasheed M.N. and Rasheed, J.M. (2016). Multicultural Social Work Practice A Competency-Based Approach to Diversity and Social. Justice. United States of America: John Wiley \& Sons, Inc.
[10] O'Shea, K. (2013). Education For Democratic Citizenship, Retrieved on the 06.11.2016fromhttp://www.edchreturkey-eu .coe.int/Source/Resources/Pack/GlossaryEDC_EN.pdf.

[11] Utah State University, Retrieved on the 06.11.2016 from $\mathrm{http}$ ://extension.usu.edu/diversity/htm/dimensions-of-diversit $\mathrm{y}$.

[12] Rijamampianina, R. \& Carmichael, T. (2005). A Pragmatic and Holistic Approach to Managing Diversity. Problems and Perspectives in Management, 1.

[13] Mazur, B. (2010). Cultural Diversity in Organisational Theory and Practice. Journal of Intercultural Management. 2(2), pp. $5-15$.

[14] Eurydice (2012). Avrupa'da vatandaşlık eğitimi. Brüksel: Eğitim, İşitsel- Görsel Medya ve Kültür Yürütme Ajans1.

[15] Güder, N. (2006) STK'lar için Gönüllülük ve Gönüllü Yönetimi Rehberi. Retreived on the 27.10. 2016 fromhttp://panel.stgm.org.tr/vera/app/var/files/g/o/gonulluluk .pdf.

[16] Balaban Yönten, A. \& İnce Çoban, İ. (2015). Gençlerin sivil toplum kuruluşlarındaki gönüllülük faaliyetleri ve gönüllülük algısı: Türkiye eğitim gönüllüleri vakfi (TEGV) örneği. Dokuz Eylül Üniversitesi İktisadi İdari Bilimler Fakültesi Dergisi, 30(2), 149-169.

[17] Bakioğlu, A. \& Kurt, T. (2009). Öğretmenlerin demokras1 vatandaşlık ve vatanseverlik algılarının nitel olarak incelenmesi. M.U. Atatürk Eğitim Fakültesi Eğitim Bilimleri Dergisi, 29, 19-39.

[18] Westheimer, J. \& J. Kahne. (2004). "What Kind of Citizen? The Politics of Educating for Democracy

[19] Patrick, J. J. (2003). “The Civic Mission of Schools: Key Ideas in a Research-Based Report on Civic Education in the United States.” ERIC Digest. ED475385, 1-7.

[20] State of the Worlds Volunteerism Report (2015), Washington: United Nations Volunteers (UNV) programme.

[21] Clary, E. G. \& Snyder, M. (1999). The Motivations to Volunteer: Theoretical and Practical Considerations. Current Directions in Psychological Science. 8(5). 156

[22] Fraenkel J. R. \& Wallen N. E. (2009), How to design and evaluation research in education. New York: McGraw-Hill.

[23] Cresswell, J. W. (2014). Research design: qualitative, quantitative, and mixed methods approaches. California: Sage.

[24] Cohen, L., Manion, L. \& Morrison, K. (2007). Research methods in education. London New York: Routledge Falmer.

[25] Yıldırım, A. \& Şimşek, H. (2013). Sosyal bilimlerde nitel araştırma yöntemleri. Ankara: Seçkin.

[26] Clough, N. V. \& Holden, C. (2002). Education for citizenship: 1deas into action: a practical guide for teachers of pupils aged 7-14. USA: Routledge.

[27] Washington, D. (2008). The concept of diversity. Washington \& Company/Permissions

[28] Pike, G. (2008). Citizenship education in global context, Brock Education, 17, 38-49.

[29] Schuitema, J. A., Ten Dam, G. \& Veugelers, W. (2008). 
Teaching strategies for moral education: a review, Journal of Curriculum Studies, 40, 69-89.

[30] Arthur, J. \& Wright, D. (2001) Teaching citizenship in the secondary school. London and New York: Routledge Taylor $\&$ Francis Group.
[31] Hickman, R. (2003) The role of art and design in citizenship education. (Ed) Addison, N. and Burgess, L. Issues in art and design teaching in (s.84-89). London and New York: Routledge Taylor \& Francis Group. 